\title{
Research of Working Capital Management Regarding to Companies in China
}

\author{
Ya Wen, Zhifei Liu, \& Cheng Huang
}

School of Management, Guangdong University of Technology, Guangzhou, CHINA

\begin{abstract}
This paper divides working capital into working capital of operating activities and working capital of financing activities. Working capital of operating activities can be further divided into working capital of procurement channels, working capital of productive channels and working capital of marketing channels by channel. Then we analyze the data in the balance sheet and income statement from Shenzhen biological, pharmaceutical listed companies in 2012 by the statistical description. Finally, we study the status of its working capital management.
\end{abstract}

Key words: Working capital; biological, pharmaceutical listed companies; Shenzhen

\section{INTRODUCTION}

$\mathrm{T}$ he global economy stays in a period of adjustment after the crisis in 2012. Although the domestic economy has already become steady the new balance has not been built. There are still many problems, such as growing cost of raw material and overcapacity, to be solved. Meanwhile, the growing popularity of the health insurance and the increasing national investments in health care can easily boost the expansion of pharmaceutical industry market. Accordingly, the competition in pharmaceutical industry is converting gradually from product to brand and the new GMP standard brings opportunities as well as challenges. As a consequence, bio-pharmaceutical industry has encouraged companies to focus on competitive enterprise and promote industrial upgrade, and as a high technology enterprise, bio-pharmaceutical industry shows high investments, high risks and high returns and enterprises always sexert a lot of effort to exploit new drugs.

Professor Zhuquan Wang was the first to propose working capital management on the basis of channel and to advocate integrating it with Supply Chain Management, Channel Management and Customer Relationship Management. He divided working capital into working capital of operating activities and working capital of financing activities, and further divided working capital of operating activities into working capital of procurement channels, working capital of productive channels and working capital of marketing channels. He has improved the traditional methods of working capital, and has brought new ideas into working capital management.

\section{SAMPLE DATA AND SuRVEy System}

The selection of the sample

We study a listed company in Shenzhen biopharmaceutical as objects. The data is obtained from CNNIC, a leading professional organization in china.

There are two main principles to follow in order to choose objects: 1. Data integrity and the relevant parameters can be calculated.2. For statistical analysis; there is a need to exclude the abnormal data or newly listed data in 2012.

Finally we select 46 listed bio-pharmaceutical companies as objects of study, according to the principles above.

\section{Indicators selected}

Stocks in procurement channels: raw materials, key materials, packaging materials, fuel, auxiliary materials, purchased semi-finished products (purchased parts), and repair parts (spare parts).

Stocks inproductive channels: work in progress, semifinished goods, consumptive biological assets, revolving materials, work in process outsourced, cost of development, and low-value consumption goods.

Stocks in marketing channels: finished goods, goods in transit, and inventory of goods.

Other stocks in small amount are not specifically classified. $50 \%$ of the other stocks figure in procurement channels, and the remains figure in the productive channels.

Specific index calculation formula:

Turnover days of working capital of marketing channel $=$ Working capital of marketing channel $\div$ (Operating income $/ 360)=($ Finished goods + Account receivable + Notes receivable- Deposit Received- Tax payable) $\div$ (Operating income/360) 
Turnover days of working capital of productive channels $=$ Working capital of productive channels $\div$ (Operating income $/ 360)=($ Work in progress + Semi-finished goods+ Other receivables+ Deferred and prepaid expenses-Employee pay payable- Other payablesAccrued Expenses) $\div$ (Operating income/360)

Turnover days of working capital of procurement channels $=$ Working capital of Procurement channels $\div$ (Operating income $/ 360)=($ Material inventory + Advance money-Accounts Payable-Notes payable $) \div$ (Operating income/360).

Turnover days of working capital of financing activities = Working capital of Financing activities $\div$ (Operating income $/ 360)=($ Cash and cash equivalents + Interest receivable+ Dividend receivable+ Transaction monetary assets and so on- Short-term loans- Accrued interest payable-Dividends Payable) $\div$ (Operating income/360) .

Income is derived from the annual income statement of "Operating income". Finished goods, notes receivable, deposit received, tax payable, other receivables, deferred, prepaid expenses, employee pay payable and so on are the mean of beginning balance and ending balance from the balanced sheet. And account receivable, other receivables and stock are the mount which indicates the net worth after deducting depreciation preparation in balanced sheet.

\section{Data sources}

As needed, the paper includes data: the beginning balance and ending balance of mobility projects from the annual balance sheet of bio-pharmaceutical listed companies(such as cash and cash equivalents, account receivable, notes receivable, advance money, other receivables, stock, shortterm loans, deposit received, notes payable, other payables and so on), operating income items from annual income statement of bio-pharmaceutical listed companies and the specific items of stock from balance sheet of biopharmaceutical listed companies. This report forms through statistical data without modifying anything.

\section{Analytical method}

Through statistical methods, we use excel to analyze the management performance of working capital in Shenzhen bio-pharmaceutical listed companies. At first, we figure out the average of working capital in every Shenzhen biopharmaceutical listed companies. Then we analyze the management situation of the companies according to the data and find out the problems of management of working capital in Shenzhen bio-pharmaceutical listed companies.

\section{THE ANALYSIS OF WORKING CAPITAL MANAGEMENT IN SHENZHEN BIO-PHARMACEUTICAL LISTED COMPANIES IN 2012}

Through statistical methods, we can figure out that the average of turnover days of working capital of marketing channel is 136.64 days. Among the 46 companies, there are 15 companies whose turnover days of working capital of marketing channel amount to or less than 100 days, 6 companies whose turnover days of working capital of marketing channel are up to 200 days and one company whose turnover days of working capital of marketing channel turns out to be a minus.

The average of turnover days of working capital of productive channel is 35.22 days. Among the 46 companies, there are 6 companies whose turnover days of working capital of productive channel are more than 50 days, 3 companies whose turnover days of working capital of productive channel are between -60 to -50 in total and 17 companies whose turnover days of working capital of productive channel turn out to be a minus.

The average of turnover days of working capital of procurement channels is 85.93 days. Among the 46 companies, there are 8 companies whose turnover days of working capital of procurement channels are more than 50 days, 6 companies whose turnover days of working capital of procurement channels is less than -50days and 23 companies whose turnover days of working capital of procurement channels turn out to be a minus.

The average of turnover days of working capital of financing activities is 57.97days. Among the 46 companies, there are 27 companies whose turnover days of working capital of financing activities are more than 50 days, 5 companies whose turnover days of working capital of financing activities are less than -50days and 11 companies whose turnover days of working capital of financing activities turn out to be a minus.

We can infer that there is a huge difference in making use of working capital among Shenzhen biological, pharmaceutical listed companies, and the average of turnover days of working capital of marketing channel is relatively higher than the others. The reasons may lie: 1.There is a huge number of finished goods stocking in the company which occupy a huge amount of money.2.There are plenty amount of account receivable we just cannot easily get it back. Excessive turnover days of working capital of marketing channel would reduce effective utilization of funds and bring down the yields, and the surplus of finished goods would undermine enterprises' anti-risk capability.

According to statistics, there are one company whose turnover days of working capital of marketing channel turns out to be a negative, 17 companies whose turnover days of working capital of productive channel turn out to be a negative, 23 companies whose turnover days of working capital of procurement channels turn out to be a negative and 11 companies whose turnover days of working capital of financing activities turn out to be a negative. With so many minus, we know it implies the instability in the use of the capital. If a company suffers from a sustaining shortage of capital, it can easily lead to the breakdown of the capital chain in the aspects of its productive, procurement or financial management. What's more there is still a potential hazard left behind. 
Table 1

Descriptive statistics

\begin{tabular}{|c|c|c|c|c|}
\hline \multirow[t]{2}{*}{ The name of the company } & \multicolumn{3}{|c|}{ Turnover days of working capital of operating Activities } & \multirow{2}{*}{$\begin{array}{l}\text { Turnover days of } \\
\text { working capital of } \\
\text { financing activities }\end{array}$} \\
\hline & $\begin{array}{c}\text { Marketing } \\
\text { channel }\end{array}$ & $\begin{array}{l}\text { Productive } \\
\text { channels }\end{array}$ & $\begin{array}{c}\text { Procurement } \\
\text { channels }\end{array}$ & \\
\hline PKU HEALTHCARE & 146.39 & -23.97 & -118.70 & -8.51 \\
\hline NORTHEAST PHARM & 136.45 & 14.34 & -34.58 & -125.18 \\
\hline $\begin{array}{c}\text { LANZHOU FOCI PHARMACEUTICAL } \\
\text { CO.,LTD }\end{array}$ & 180. 23 & 21.08 & 55.35 & 245.01 \\
\hline HANSEN PHARM & 88.30 & -22.85 & 18.14 & 486.63 \\
\hline HUAPONT-NUTRICHEM CO.,LTD & 97.83 & -1.59 & -54.63 & -20.83 \\
\hline $\begin{array}{c}\text { CHINA RESOURCES SANJIU } \\
\text { MEDICAL\&PHARMACEUTICALCO,.LTD }\end{array}$ & 96.22 & -56.34 & -20.13 & 300.38 \\
\hline $\begin{array}{l}\text { HUASUN } \\
\end{array}$ & 161.70 & 0.84 & -67.41 & 44.81 \\
\hline JINLING PHARMACEUTICAL CO.,LTD & 111.39 & -17.39 & -15.92 & 150.27 \\
\hline JIU ZHI TANG & 125.01 & -56.97 & -4.89 & 234.53 \\
\hline QINGHAI GELATIN COMPANY LIMILED & 141.54 & 8.36 & 16.44 & 13.57 \\
\hline RENHE PHARMACY CO.,LTD & 80.79 & -5.17 & -13.02 & 62.38 \\
\hline TONGHUA GOLDEN-HOURSE GROUP & 403.04 & 602.36 & 84.81 & 20.25 \\
\hline ZHEJIANG NHU COMPANY LTD & 106.60 & 53.91 & -21.90 & 215.43 \\
\hline $\begin{array}{c}\text { SHANDONG XINHUA } \\
\text { PHARMACEUTICAL CO.,LTD }\end{array}$ & 9.20 & -13.45 & -37.92 & -16.08 \\
\hline $\begin{array}{l}\text { ZHEJIANG HANGZHOU XINFU } \\
\text { PHARMACEUTICAL CO.,LTD }\end{array}$ & 146.58 & 4.52 & -9.59 & -205.12 \\
\hline XIN BANG & 198.71 & 97.38 & 72.20 & 187.49 \\
\hline YUNNAN BAIYAO & 109.08 & 8.16 & -28.35 & 37.55 \\
\hline ZHONGSHENG PHARMACY & 104.30 & -17.66 & 20.67 & 365.94 \\
\hline BBCA PHARMACEUTICAL & 87.57 & -0.35 & -20.68 & -45.05 \\
\hline DEEJ & -1.90 & -18.92 & 9.29 & 356.27 \\
\hline LIVZON & 79.14 & -38.86 & 3.00 & 52.59 \\
\hline HAIYAO & 140.90 & 55.10 & 20.90 & 127.32 \\
\hline $\begin{array}{l}\text { UNISPLENDOUR GUHAN GROUP } \\
\text { CORPORATION LIMITED }\end{array}$ & 200.78 & 7.13 & -45.17 & 61.01 \\
\hline JI LIN AODONG & 97.14 & -22.25 & 17.50 & 271.98 \\
\hline APELOA & 88.62 & 3.14 & -98.75 & -46.19 \\
\hline GUANGJI PHARM & 220.33 & -67.31 & -150.83 & -111.72 \\
\hline $\begin{array}{c}\text { ZHEJIANG JINGXIN PHARMACEUTICAL } \\
\text { CO.,LTD } \\
\end{array}$ & 68.52 & 8.75 & -38.68 & 44.93 \\
\hline HISOAR PHARMACEUTICAL & 111.51 & 29.12 & -34.90 & -19.63 \\
\hline WOHUA PHARMACEUTICALS & 158.59 & 18.32 & 5.98 & 498.89 \\
\hline $\begin{array}{l}\text { JILIN ZIXIN PHARMACEUTICAL } \\
\text { INDUSTRIAL CO.,LTD } \\
\end{array}$ & 474.66 & 307.16 & 164.13 & -604.77 \\
\hline LAYN & 126.70 & 526.27 & -101.71 & -342.51 \\
\hline JIAYING PHARMACEUTICAL & 122.41 & 19.55 & 17.78 & 29.89 \\
\hline HENGKANG MEDICAL GROUP & 106.90 & 28.36 & 41.80 & 143.80 \\
\hline EHWA & 81.53 & 0.52 & -40.76 & 17.16 \\
\hline SANJIN & 99.66 & -12.08 & -16.69 & 19.92 \\
\hline QIZHENG & 162.81 & 0.18 & 40.77 & 199.95 \\
\hline NT JHZY & 146.32 & -9.36 & -20.34 & 149.20 \\
\hline YATAI & 206.52 & 20.19 & -45.06 & 316.05 \\
\hline $\begin{array}{l}\text { TIJINLISHENG PHARMACEUTICA } \\
\text { CO.,LTD }\end{array}$ & 106.00 & 14.20 & 6.14 & 541.71 \\
\hline HEPALINK & 75.04 & 58.67 & 50.40 & 1374.41 \\
\hline KL INDUSTRY GROUP & 183.28 & 2.05 & 5.72 & 97.18 \\
\hline GUIZHOU BAILING & 255.11 & 33.00 & 21.90 & 78.47 \\
\hline TAIANTANG & 129.97 & -10.90 & 188.37 & 202.38 \\
\hline GLORIA PHARMACEUTICALS & 15.48 & 22.23 & 127.11 & 711.49 \\
\hline YISHENG-PHARMACEACEUTICA & 193.47 & 22.57 & 43.50 & 531.94 \\
\hline $\begin{array}{c}\text { SHIJIAZHUANG YILING } \\
\text { PHARMACEUTICAL CO.,LTD }\end{array}$ & 104.59 & 28.28 & 102.54 & 354.94 \\
\hline
\end{tabular}




\section{CONCLUSION}

Turnover days of working capital are a comprehensive indicator, and exploring working capital through the channel helps enterprise realize its shortage in the aspects of productive, procurement and marketing channel and find ways to improve it. Also there are some places we need to improve: First of all, the extent is limited to the year 2012, and it doesn't rule out non-routine inputs or outputs which perhaps could impact the validity of the result. Secondly, the research doesn't fully eliminate the irrelevant factors that may affect the conclusion to some extent. Thirdly, we regard biological, pharmaceutical listed companies as objects of study, although it is particular, but it is not easy to compare in a single industry.

\section{REFERENCE}

[1] Zhuquan Wang, Wenjing Liu, Xinghe Wang, J., 2009.A survey about working capital of Chinese listed companies: 2007-2008.J.Accounting Research.51-58.

[2] The research group about working capital management of china enterprise in University, J., 2010. A survey about working capital of Chinese listed companies J. Accounting Research.30-42.

[3] Zhuquan Wang, Ying Sun, Xiuhua Wang.2011. A survey about working capital of Chinese listed companies: 2010. J. Accounting Research.52-63.

\section{Why Open Access ???}

"In the traditional publishing model, readers have limited access to scientific papers; authors do not have copyright for their own papers, and cannot post their papers on their own websites, which presents a significant barrier to the sharing of knowledge, as well as being unfair to authors. Open access can overcome the drawbacks of the traditional publishing model and help scholars build on the findings of their colleagues without restriction"

\section{Submit your next manuscript at- www.abcjournals.net}

$A B C$ Journals is a unique forum to offer open access to all of its articles.

Now ABC Journal's portfolio is over nine journals, which publish both online and in print. 